\title{
Modulatory effects of neuropeptides on pentylenetetrazol-induced epileptic seizures and neuroinflammation in rats
}

\section{SUMMARY}

OBJECTIVE: We aimed to explore the effects of neuropeptides ghrelin, obestatin, and vasoactive intestinal peptide (VIP) on seizures and plasma concentrations of neuroinflammation biomarkers including calcitonin gene-related peptide (CGRP), substance-P (SP), and interleukin-1 beta (IL-1B) in pentylenetetrazol-induced seizures in rats.

METHODS: Ghrelin $(80 \mu \mathrm{g} / \mathrm{kg})$, obestatin $(1 \mu \mathrm{g} / \mathrm{kg})$, VIP $(25 \mathrm{ng} / \mathrm{kg})$ or saline were administered to rats intraperitoneally 30 min before pentylenetetrazole (PTZ, $50 \mathrm{mg} / \mathrm{kg}$ ) injections. Stages of epileptic seizures were evaluated by Racine's scale, and plasma CGRP, SP, and IL-7 $\beta$ concentrations were measured using ELISA.

RESULTS: Both obestatin and VIP shortened onset-time of generalized tonic-clonic seizure, respectively, moreover VIP also shortened the onset-time of first myoclonic-jerk induced by PTZ. While PTZ increased plasma CGRP, SP and IL-1 $\beta$ concentrations, ghrelin reduced the increases evoked by PTZ. While VIP further increased PTZ-evoked CGRP levels, it diminished IL-1 $\beta$ concentrations. However, obestatin did not change CGRP, SP, and IL-T $\beta$ concentrations.

CONCLUSION: Our results suggest that ghrelin acts as an anticonvulsant, obestatin acts as a proconvulsant, and VIP has dual action on epilepsy. Receptors of those neuropeptides may be promising targets for epilepsy treatment.

KEYWORDS: Epilepsy. Neuroinflammation. Ghrelin. Vasoactive intestinal peptide. Obestatin.

\section{INTRODUCTION}

There are plenty of data suggesting that neuroinflammation is involved in the pathophysiology of epilepsy. ${ }^{1}$ It has been reported that neuroinflammation leads to excessive neuronal discharges in the seizure. ${ }^{2}$ Although neuroinflammation is considered to play a key role in the pathophysiology of epilepsy, neuroinflammatory processes underlying epileptogenesis are still unclear. An experimental study with transgenic mice overexpressing pro-inflammatory cytokines, such as TNF- $\alpha$ and IL-6, in astrocytes reported that age-dependent reduced seizure threshold and spontaneous seizures developed in these mice. ${ }^{3}$ In addition, it was reported that inhibition of IL-1 $\beta$ signaling resulted in the inhibition of seizure generalization and increased the seizure threshold in the surrogate kindling model of epileptogenesis in rats. ${ }^{4}$ 
It is well established that the calcitonin gene-related peptide (CGRP) and substance P (SP) released from trigeminal sensory fibers lead to neurogenic inflammation by inducing vasodilatation and plasma protein extravasation in the meninges. ${ }^{5}$ Therefore IL-1 $\beta$, CGRP, and SP are biomarkers of neuroinflammation in the brain and meninges.

Neuropeptides are regulators of a wide range of physiological processes in the nervous system.

Ghrelin, obestatin and vasoactive intestinal peptide (VIP) are neuropeptides synthesized in both the gastrointestinal system and the central and peripheral nervous systems. These neuropeptides have key roles in a lot of physiological and pathophysiological events because their receptors are widely distributed through the nervous and gastrointestinal systems.

Although there are some studies on the effects of ghrelin, obestatin, and VIP on epileptic seizures, their effects on the neuroinflammation underlying pathogenesis of epilepsy remain unclear. Therefore, in the present study, we investigated the effects of neuropeptides ghrelin, obestatin, and VIP on seizures and plasma concentrations of neuroinflammation biomarkers, including CGRP, SP, and IL-1beta in pentylenetetrazol-induced seizures in rats.

\section{METHODS}

\section{Experimental Animals}

Thirty-five Wistar male rats (200-250 g) were used in the study. The animals were fed standard pellets ad libitum and tap water and were housed in cages under standard conditions, including a 12 hour light/dark cycle at $22 \pm 2{ }^{\circ} \mathrm{C}$. The experimental processes were approved by the Animal Experiment Local Ethics Committee of the University (license number 2018/04).

\section{Materials}

Pentylenetetrazole, ghrelin, obestatin, and vasoactive intestinal peptide were purchased from Sigma-Aldrich (Schnelldorf, Germany). CGRP, SP, and IL-1 beta ELISA kits were purchased from ELABscience (Wuhan, P.R. China ), ketasol (10 \%) was purchased from Richter Pharma (Wels, Austria).

\section{Experimental groups and procedures}

Thirty-five rats were randomly divided into five groups, with seven rats in each group $(n=7)$. All injections were carried out intraperitoneally. Rats in the control group were administered $0.2 \mathrm{ml}$ normal saline and received another $0.2 \mathrm{ml}$ normal saline dose 30 min after the first injection. Rats in the PTZ group were administered $0.2 \mathrm{ml}$ normal saline and received $50 \mathrm{mg} / \mathrm{kg}$ pentylenetetrazole $30 \mathrm{~min}$ after the normal saline injection. Rats in the Ghrelin+PTZ group were administered $80 \mu \mathrm{gg} / \mathrm{kg}_{\text {ghrelin }}{ }^{6}$ and received 50 $\mathrm{mg} / \mathrm{kg}$ pentylenetetrazole $30 \mathrm{~min}$ after the ghrelin injection. Rats in the Obestatin+PTZ group were administered $1 \mu \mathrm{g} / \mathrm{kg}$ obestatin ${ }^{7}$ and received $50 \mathrm{mg} / \mathrm{kg}$ pentylenetetrazole $30 \mathrm{~min}$ after the obestatin injection. Rats in the VIP+PTZ group were administered $25 \mathrm{ng} / \mathrm{kg}$ vasoactive intestinal peptide ${ }^{8}$ and received $50 \mathrm{mg} / \mathrm{kg}$ pentylenetetrazole $30 \mathrm{~min}$ after vasoactive intestinal peptide injection.

\section{Induction and scoring of epileptic seizures}

In order to induce a seizure, rats were administered PTZ with a single dose of $50 \mathrm{mg} / \mathrm{kg}$ as stated previously. ${ }^{6}$ After PTZ injections, the rats were placed in plexiglass cages $(40 \mathrm{~cm} \mathrm{X} 40 \mathrm{~cm}$ X $30 \mathrm{~cm})$ and their behavior was videotaped for $30 \mathrm{~min}$. The intensity of seizures was assessed using Racine's scoring (0-5) as follows ${ }^{9}$ : stage 0 , no response; stage 1 , facial movements with vellication of ears and whiskers; stage 2, myoclonic jerks without rearing; stage 3, clonus of one forelimb; stage 4 , rearing with bilateral forelimb clonus; stage 5 , generalized tonic-clonic seizures.

\section{Blood sample collection from animals}

Blood samples were taken from the right ventricle $24 \mathrm{~h}$ after the PTZ injections and coagulated at room temperature for $30 \mathrm{~min}$. Then, blood samples were centrifuged at $3000 \mathrm{rpm}$ for $15 \mathrm{~min}$ at $4{ }^{\circ} \mathrm{C}$, and supernatants were kept at $-80^{\circ} \mathrm{C}$ until assayed for CGRP, SP, and IL-1 $\beta$ immunoreactivities.

\section{Determination of plasma CGRP, SP and IL-1 beta concentrations}

CGRP, SP, and VIP contents in plasma samples were measured using the ELISA method with detection kits (ELABscience, Wuhan, P.R. China). The detection limit for CGRP is $\sim 9 \mathrm{pg} / \mathrm{ml}$; for SP is $\sim 47 \mathrm{pg} /$ $\mathrm{ml}$; and for IL-1 $\beta$ is $\sim 19 \mathrm{pg} / \mathrm{ml}$. The assay procedures were performed following the manufacturer's instructions and in duplicates. After samples or CGRP, IL-1 $\beta$, SP standards were added and the 96-well plates incubated according to the instructions, the optical densities for CGRP, SP, and IL-1 $\beta$ were measured at 

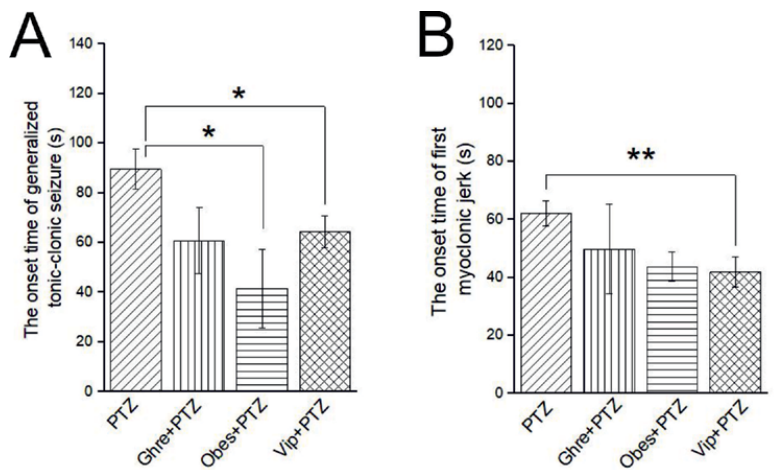

FIGURE 1. EFFECTS OF GHRELIN, OBESTATIN, AND VASOACTIVE INTESTINAL PEPTIDE ON THE ONSET TIME OF GENERALIZED TONIC-CLONIC SEIZURE (A) AND ONSET TIME OF FIRST MYOCLONIC JERK (B) IN PTZ-INDUCED EPILEPTIC RATS. ${ }^{*} \mathrm{P}<0.05,{ }^{* \star} \mathrm{P}<0.01$
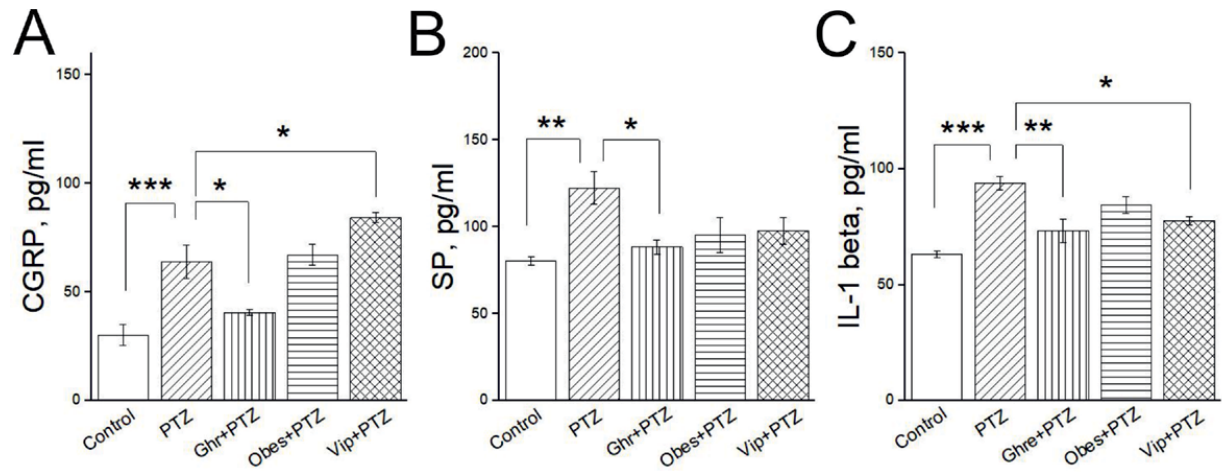

FIGURE 2. EFFECTS OF GHRELIN, OBESTATIN, AND VASOACTIVE INTESTINAL PEPTIDE ON THE PLASMA $\operatorname{CGRP}(A), S P(B)$ AND IL-1 $\operatorname{BETA}(C)$ LEVELS IN PTZINDUCED EPILEPTIC RATS. ${ }^{*} P<0.05,{ }^{* *} P<0.01$, ${ }^{* * *} P<0.001$

$450 \mathrm{~nm}$ using a microplate reader (Epoch BioTek Instruments, Inc. Highland Park, Winooski, VT, USA).

\section{STATISTICAL ANALYSIS}

The data were given as mean \pm standard error of the mean. Statistical analysis was performed using SPSS for Windows (version 17.0, SPSS Inc., Chicago, IL, USA). Data obtained from the experimental groups were analyzed by one-way analysis of variance followed by Tukey's multiple comparisons test. $A$ value of $p<0.05$ was considered statistically significant.

\section{RESULTS}

The effects of ghrelin, obestatin, and VIP on the duration of the characteristic behavioral changes in PTZ-induced epileptic rats

The obestatin treatment shortened the onset-time of the generalized tonic-clonic seizure $(\mathrm{P}=0.037$, Fig. 1A) compared to the PTZ group. Moreover, VIP shortened the onset-time of the generalized tonic-clonic seizure $(\mathrm{P}=0.039$, Fig. $1 \mathrm{~A})$ and first myoclonic-jerk $(\mathrm{P}=0.009$, Fig. 1B), respectively. On the other hand, ghrelin changed neither the generalized tonic-clonic seizure ( $\mathrm{P}=0.075$, Fig. $1 \mathrm{~A})$ nor the first myoclonic-jerk $(\mathrm{P}=0.791$, Fig. 1B) compared to the $\mathrm{PTZ}$ group.

The effects of ghrelin, obestatin, and VIP on plasma CGRP, SP, and IL-1 beta concentrations in PTZ induced-epileptic rats

The pentylenetetrazol treatment led to significant increases in the plasma CGRP ( $\mathrm{P}=0.001$, Fig. $2 \mathrm{~A})$, SP ( $\mathrm{P}=0.003$, Fig. $2 \mathrm{~B})$, and IL-1 beta ( $\mathrm{P}=0.001$, Fig. $2 \mathrm{C})$ concentrations compared to the normal saline-treated control group. On the other hand, ghrelin pretreatment decreased PTZ-induced plasma CGRP ( $\mathrm{P}=0.013$, Fig. $2 \mathrm{~A})$, SP ( $\mathrm{P}=0.02$, Fig. $2 \mathrm{~B})$, and IL-1 beta ( $\mathrm{P}=0.001$, Fig. 2C) concentrations (PTZ group versus ghrelin+PTZ group).

Obestatin pretreatment did not show any effect on the PTZ-induced plasma CGRP, SP and IL-1 beta concentrations $(\mathrm{P}=0.98$ for CGRP, Fig. 2A; $\mathrm{P}=0.09$ for SP, Fig. 2B; and $\mathrm{P}=0.283$ for IL-1 beta Fig. $2 \mathrm{C}$ ). While VIP pretreatment further increased PTZ-induced plasma CGRP concentration ( $\mathrm{P}=0.038$, Fig. $2 \mathrm{~A})$, it decreased PTZ-induced plasma IL-1 beta concentration ( $\mathrm{P}=0.011$, Fig. 2C, PTZ group versus VIP+PTZ group). However, VIP pretreatment did not show any effect on the PTZ-induced plasma SP concentration ( $\mathrm{P}=0.147$, Fig. 2B).

\section{DISCUSSION}

Existing antiepileptic drugs (AEDs) target ion channels or ionotropic receptors of excitatory or in- 
hibitory neurotransmitters. Approximately one-third of patients with epilepsy do not correctly respond to any of these AEDs. ${ }^{10}$ Therefore, neuropeptide-mediated modulation of synaptic transmission may represent a novel treatment approach for patients suffering from different types of epilepsy. Pursuant to this hypothesis, we explored the effects of neuropeptides ghrelin, obestatin, and VIP on PTZ-evoked epileptic seizures and neuroinflammation markers including IL-1 $\beta$, CGRP, and SP.

In the present study, ghrelin attenuated plasma CGRP, SP, and IL-1 $\beta$ concentrations induced by PTZ. This result is important because CGRP, SP, and IL$1 \beta$ are key biomarkers of neuroinflammation. Moreover, inflammatory processes in the brain have been implicated in the pathophysiology of seizures and epilepsy. ${ }^{11}$ An inflammation without infection in the central nervous system is called sterile inflammation characterized by the release of vasoactive neuropeptides, including CGRP and SP, from sensory nerves. ${ }^{5} \mathrm{SP}$ has a great role in inflammatory processes. Moreover, cytokines such as IL-1 $\beta$ are also released by the glia and neurons in the CNS in addition to immune cells and endothelial cells during neuro-inflammation. ${ }^{12}$

Most clinical studies have reported that plasma IL-1 $\beta$ levels were higher in children with febrile seizures than controls. ${ }^{13}$ Furthermore, it is well established that IL-1 $\beta$ has a key role in exacerbating seizures in animal models of epilepsy. ${ }^{14}$ On the other hand, in the present study, ghrelin did not show any significant effect on the PTZ-induced generalized tonic-clonic seizure or first myoclonic-jerk. In a previous study, it was reported that ghrelin repressed the onset time of PTZ-induced seizures in rats. ${ }^{6}$ Although consensus claims that ghrelin has an anticonvulsant action, some studies report that ghrelin did not have any effect on the seizures. One of those studies reported that ghrelin fails to inhibit seizures induced by kainic acid or pilocarpine. ${ }^{15}$ Like those studies, we also did not find any effect of ghrelin on the characteristic behavioral changes of epilepsy. However, we first demonstrate the modulating effect of ghrelin on PTZ-induced plasma CGRP, SP, and IL-1 $\beta$ levels. These results suggest that ghrelin may alleviate seizures by decreasing the the neuroinflammation underlying pathophysiology of epilepsy.

Unlike ghrelin, there are some studies about the effects of obestatin on epilepsy. In a clinical study, it was found that plasma concentrations of obesta- tin were higher in patients with primary generalized and partial epilepsy than in controls. ${ }^{16}$ In line with this study, we found that obestatin shortened the onset-time of generalized tonic-clonic seizure while it did not affect the onset-time of first myoclonic-jerk in PTZ-induced seizures in rats. Therefore, our results suggest that obestatin has a proconvulsant effect on the behavioral characteristics of PTZ-induced seizure. Contrarily, a recent study reported that obestatin alleviated the intensity of PTZ-induced seizures and decreased neuronal damage by delimitating oxidative damage in rats. ${ }^{7}$ This difference may be due to the measurement of different parameters, and, therefore, more clinical and experimental studies are needed to explain the possible mechanisms of these differences. Interestingly, in the present study, the obestatin pretreatment did not change plasma levels of biomarkers associated with neuroinflammation including CGRP, SP and IL-1 beta. Based on these results, we can speculate that obestatin might not exhibit its proconvulsant action through neuroinflammatory mechanisms.

VIP is a neuropeptide that has anti-inflammatory and neuroprotective effects. However, VIP can play a key role in seizure disorders because it demonstrates excitatory effects on synaptic transmission in different brain regions, such as the hippocampus. It has been demonstrated that there was a short-term decrease in brain VIP concentrations after PTZ-induced seizures in rats. ${ }^{17}$ Conversely, a clinical study reported that VIP concentrations were higher in the serum and cerebrospinal fluid of children with seizure disorders than in controls. ${ }^{18}$ In the present study, we found that VIP shortened both onset-time of generalized tonic-clonic seizure and first myoclonic-jerk. Moreover, VIP pretreatment further enhanced plasma CGRP levels induced by PTZ. These findings indicate that VIP exhibits a proconvulsant effect on the behavioral characteristics of seizure and also exacerbates neuroinflammation induced by PTZ. However, in the current study, interestingly, VIP alleviated PTZ-induced plasma IL-1 $\beta$ levels. Therefore we can speculate that VIP exacerbates seizures by shortening the onset-time of generalized tonic-clonic seizure and first myoclonic-jerk and also by increasing CGRP levels. VIP also endeavors to protect neuroinflammation by reducing IL-1 $\beta$ levels. These results indicate that VIP may have a dual role in the generation of seizures.

As a whole, our results suggest that ghrelin has 
an anticonvulsant action, obestatin has a proconvulsant action, and VIP has dual action on epilepsy. Receptors of neuropeptides ghrelin, obestatin, and VIP may be favorable targets for epilepsy treatment. However, studies with specific agonists and antagonists of these receptors are needed.

\section{Acknowledgments}

We declare there was no conflict of interest in this paper.

This study was presented as a poster in the 44th
National Physiology Congress, 01 - 04 November 2018, Antalya, Turkey, and the abstract was published in Acta Physiologica, vol. 225, issue S716.

\section{Contributions of authors}

Erkan Kilinc: Hypothesis, conception, design of research, statistical data analysis, manuscript preparation, final approval

Handan Gunes: Implementation of experiments, data acquisition, manuscript preparation, production of graphics, final approval.

\section{RESUMO}

OBJETIVO: Nosso objetivo foi explorar os efeitos dos neuropeptídeos grelina, obestatina e peptídeo intestinal vasoativo (VIP) nas convulsões e concentrações plasmáticas de biomarcadores neuroinflamatórios, incluindo peptídeo relacionado ao gene da calcitonina (CGRP), substância-P (SP) e interleucina-1 beta (IL-1ß) em convulsões induzidas por pentilenotetrazol em ratos.

MÉTODOS: Grelina (80 $\mathrm{\mu g} / \mathrm{kg})$, obestatina $(1 \mu \mathrm{g} / \mathrm{kg})$, VIP $(25 \mathrm{ng} / \mathrm{kg})$ ou solução salina foram administrados a ratos intraperitonealmente 30 minutos antes de injeções de pentilenotetrazol (PTZ, $50 \mathrm{mg} / \mathrm{kg}$ ). Os estágios das crises epilépticas foram avaliados pela escala de Racine e as concentrações plasmáticas de CGRP, SP e IL-1ß foram medidas usando Elisa.

RESULTADOS: Tanto a obestatina quanto o VIP encurtaram o tempo de início da crise tônico-clônica generalizada, respectivamente. Além disso, o VIP também encurtou o tempo de início do primeiro impulso mioclônico induzido por PTZ. Enquanto o PTZ aumentou as concentrações plasmáticas de CGRP, SP e IL-7 $\beta$, a grelina reduziu os aumentos evocados por PTZ. Enquanto o VIP aumenta ainda mais os níveis de CGRP evocados por PTZ, diminui as concentrações de IL-1 $\beta$. No entanto, a obestatina não alterou as concentrações de CGRP, SP e IL-1ß

CONCLUSÃO: Nossos resultados sugerem que a grelina tem anticonvulsivante, a obestatina tem proconvulsivante e o VIP tem ação dupla na epilepsia. Receptores desses neuropeptídeos podem ser alvos promissores para o tratamento da epilepsia.

PALAVRAS-ChaVe: Epilepsia. Encefalite. Grelina. Peptídeo intestinal vasoativo. Ratos.

\section{REFERENCES}

1. Vezzani A, French |, Bartfai T, Baram TZ. The role of inflammation in epilepsy. Nat Rev Neurol. 2011;7(1):31-40

2. Granata T, Cross H, Theodore W, Avanzini G. Immune-mediated epilepsies. Epilepsia. 2011;52(Suppl 3):5-11.

3. Probert L, Akassoglou K, Kassiotis G, Pasparakis M, Alexopoulou L, Kollias G. TNF-alpha transgenic and knockout models of CNS inflammation and degeneration. J Neuroimmunol. 1997;72(2):137-41.

4. Auvin S, Shin D, Mazarati A, Sankar R. Inflammation induced by LPS enhances epileptogenesis in immature rat and may be partially reversed by IL1RA. Epilepsia 2010;51(Suppl 3):34-8.

5. Ramachandran R. Neurogenic inflammation and its role in migraine. Semin Immunopathol. 2018;40(3):301-14.

6. Obay BD, Tasdemir E, Tümer C, Bilgin HM, Sermet A. Antiepileptic effects of ghrelin on pentylenetetrazole-induced seizures in rats. Peptides. 2007;28(6):1214-9.

7. Koyuncuoğlu T, Vızdıklar C, Üren D, Yılmaz H, Yıldırım Ç, Atal SS, et al. Obestatin improves oxidative brain damage and memory dysfunction in rats induced with an epileptic seizure. Peptides. 2017;90:37-47.

8. Kilinc E, Firat T, Tore F, Kiyan A, Kukner A, Tunçel N. Vasoactive intestinal peptide modulates c-Fos activity in the trigeminal nucleus and dura mater mast cells in sympathectomized rats. J Neurosci Res. 2015;93(4):644-50.

9. Racine R|, Gartner |G, Burnham WM. Epileptiform activity and neural plasticity in limbic structures. Brain Res. 1972;47(1):262-8.

10. Perucca E, French J, Bialer M. Development of new antiepileptic drugs: challenges, incentives, and recent advances. Lancet Neurol. 2007;6(9):793-804
11. Riazi K, Galic MA, Pittman Q|. Contributions of peripheral inflammation to seizure susceptibility: cytokines and brain excitability. Epilepsy Res. 2010;89(1):34-42

12. Bartfai T, Schultzberg M. Cytokines in neuronal cell types. Neurochem Int. 1993;22(5):435-44.

13. Li G, Bauer S, Nowak M, Norwood B, Tackenberg B, Rosenow F, et al. Cytokines and epilepsy. Seizure. 2011;20(3):249-56

14. Vezzani A, Moneta D, Conti M, Richichi C, Ravizza T, De Luigi A, et al. Powerful anticonvulsant action of IL-1 receptor antagonist on intracerebral injection and astrocytic overexpression in mice. Proc Nat Acad Sci USA. 2000;97(21):11534-9.

15. Biagini G, Torsello A, Marinelli C, Gualtieri F, Vezzali R, Coco S, et al. Beneficial effects of desacyl-ghrelin, hexarelin and EP-80317 in models of status epilepticus. Eur | Pharmacol. 2011;670(1):130-6.

16. Dag E, Aydin S, Ozkan Y, Erman F, Dagli AF, Gurger M. Alteration in chromogranin A, obestatin and total ghrelin levels of saliva and serum in epilepsy cases. Peptides. 2010;31(5):932-7.

17. Romualdi P, Lesa G, Donatini A, Balboni G, Tomatis R, Ferri S. Alterations in vasoactive intestinal polypeptide-related peptides after pentylenetetrazole-induced seizures in rat brain. Eur | Pharmacol. 1992;229(2-3):149-53.

18. Ko FJ, Chiang CH, Liu WJ, Chiang W. Somatostatin, substance P, prolactin and vasoactive intestinal peptide levels in serum and cerebrospina fluid of children with seizure disorders. Gaoxiong Yi Xue Ke Xue Za Zhi. 1991;7(8):391-7. 